\title{
Effect of Entrepreneurship Characteristic, Government Commitment and Business Competence on Performance of Small Micro Enterprise in Balikpapan
}

\author{
I GustiPutu Darya
}

\section{Background}

\section{Introduction}

Going into twentieth century economic uncertainty haunt most people in the world, including Indonesia., even about 47 million households in Indonesia or about 52 percent is in pre welfare household and welfare one household, with few shock may include in poor household (Suyono:2001).

To deal with the problem, household-based micro business activity should be developed that is often assumed with people economic idea that is local oriented economy. Macro national economy development is not enough. So development of micro economic business development as complementary activity is a very strategic requirement, particularly in realizing welfare for all people, (Sunarno, 2003).

Widoatmodjo (2002:31) said that impact of monetary crisis as one of business phenomena is wide and difficult. Even in Indonesia monetary crisis have impact on political life and its difficulty is still felt until now.

Gorman (1997:67), Kourlisky and Walstand (1998; 101) in Clement K Wang et al (2004; 72) in research in Singapore stated that impact of entrepreneurship education may help youth to understand and induce entrepreneurship spirit. Although many students in Singapore want to run their own business, their dream is hampered with insufficient preparation, less knowledge on business, and more important, their unreadiness to take risk to realize their dream.

Existence of small micro enterprise (SME) that is most part of national economy is indicator of people participation in various economic sectors. Small micro enterprise is proved being reliable as securing key in critical time, through mechanism of creating working opportunity and added value. The strategic role and function may be improved by playing small micro enterprise as one of complementary business actor for developing national economy. Success in increasingsmall micro enterprise capability means strengthening people economic business, accelerating national economy recovery and giving real support on local government in doing government autonomy.

Small micro enterprise is still survive at crisisdue to (1) having no foreign debt, (2) no many debt to bank because they are considered unbankable, (3) using local input, and (4) export orientation (Kuncoro, 2008).

Small micro enterprise ideally requires government intervention in increasing competition. However, capability of SME is not to compete with big business (industry), but more on capability to predict business environment and capability to anticipate the environment condition. Role of government is not as capital provider, but on assistance of small business and create condition supportingcapability of small industry in accessing capital. Government should encourage capability of small industry in calculating required optimal capital, capability in making financing proposal to capital provider institution, and issue policy or regulation promoting small industry in credit provision (Pardede, 2000:38).

\section{Problem formulation}

Research problems are formulated as follows:

1) Do entrepreneurship characteristics affect business competence?

2) Do entrepreneurship characteristics affect performance?

3) Does government commitment affect business competency?

4) Does government commitment affect performance?

5) Doesbusinesscompetence affect performance?

\section{Objective}

The research has objective to prove and analyze effect of some variables on small micro enterprise in Balikpapan including (1) entrepreneurship characteristic to business competence, (2) entrepreneurship characteristic to business performance, (3) government commitment to business competence, (4) government commitment to business performance, (5) business competence on business performance. 


\section{Benefit}

Some benefit expected from the result research is theoretical and practical benefit. Theoretical benefits of the research include (1) providing contribution in developing economic science, (2) providing contribution in people economic study in using quantitative model and empirical testing, (3) and contributing for future researcher through theoretical model that is not tested thoroughly in this dissertation.

Practical benefit of the research are (1) provide deeper understanding on entrepreneurship characteristic, government commitment on business competence and performance of small micro enterprise in Balikpapan, (2) information of source for government in empowering small micro enterprise to improve people welfare of small micro enterprise actor in particular and society in general, and (3) as reference for government of Balikpapan in making decision or policy to empower small micro enterprise as one of pillars in empowering people economy.

\section{Theoretical Base}

\section{Definition of entrepreneurship}

In annex of Decree of Cooperative and small entrepreneur assistance Minister number 961/KEP/M/XI/1995, entrepreneur is person having spirit, attitude, behavior and capability of entrepreneurship, (b) entrepreneurship is spirit, attitude, behavior and capability of someone in handling business or activity to lookfor, create and apply procedure, technology and new product by increasing efficiency in order to give better service and or obtain greater profit.

Some definitions on entrepreneurship are given by Jean Baptista Say (1816), Frank Knight (1921), and Joseph Schumpeter (1934). They give definition of entrepreneurship as innovator that implement changes in market through new combination. The new combination may be (1) introducing new product with new quality, (2) introduce new production method, (3) open new market, (4) obtain new supply source from new material or component, or (5) run new organization in an industry.

\section{Government commitment}

a. Creating climate for small micro enterprise

Article 7 of Law number 20/ 2008 stipulatescentral and local governments create business climate by enforcing laws and policy including aspects of (a) financing, (b) infrastructure, (c) business information, (d) partnership, (e) business permits, (f) business opportunity, (g) business promotion and (h) institutional support.

Access of small micro enterprise to credit as intended was done by (a) increasing capability of preparing business feasibility study, (b) increasing knowledge on procedure of applying credit and (c) increasing understanding and technical skill and business managerial.

b. Government support on small micro enterprise

Government through Cooperation and small micro enterprise ministry prepare financing program for women and youth through micro business in the 2010 government working budget plant. Total budget available was 130 billion rupiah for 2600 women and youth groups as micro business actor.

\section{Business competence}

Before further discuss on importance of competence in performance evaluation process, it is better to understand what competence is. Berge $\mathrm{Z}$ et al (2002:79) in A. Agustinah (2008:87) stated many different definitions on competition that resulting in wide framework, but not all suit and may be debatable. (1) Law no 20/2003 on National Education System article 35 paragraph (1) stipulates graduate competence is qualification of graduate capability including attitude, knowledge and skill according to agreed national standard. (2) Law no 13/2003 concerning manpower affair article 1 paragraph (1) stipulates "competence is working capability of each individual including knowledge, skill and working attitude of each individual including knowledge, skill and working attitude according to determined standard". (3) GovernmentRegulation no 23 of 2004 on National ProfessionCertification Body (BNSP) explain certification of working competence as a process providing competence certificate done systematically and objective through competence test referring to Indonesia or international working competence standard. (4) Definition on Competency Based Training (CBT) an approach in training emphasizing on what individual can demonstrate: knowledge, skill and professional attitude, in work place according to industrial standard as result of training. (5) According to Indonesian National Working competence standard, competence is statement on what one can demonstrate: skill, knowledge, and attitude in working place according to industrial standard or to requirementdetermined by working place. (6) Lyle M. Spencer and Signe Spencerstate in their work, Competence at Work: Models for Superior Performance 1993. 


\section{Definition of small micro enterprise}

a. According to Central Statistical Bureau

Small business understanding should be confirmed considering some sources give different criteria on small business such as Central statistical Bureau use guidance of manpower in defining small business, in which small business is a business using 5 to 19 persons.

b. According to Bank Indonesia

Bank Indonesia give criteria on business called as small business by emphasizing on asset had as business field, where small business in trade and service less thanRp 40 million; industry and building when its asset less than $\mathrm{Rp} 100$ million

c. According to Industry Ministry

Industry Ministry give definition of small businessaccording to investment in which business is categorized as small business when its investment les than Rp 79 million. But along with its development, in 1990, a small business is defined with asset of Rp 600 million added with provision that its owner is Indonesian.

\section{Thinking frame}

\section{Thinking Process Frame}

In order to make research is directed, a thinking process frame is created based on below figure.

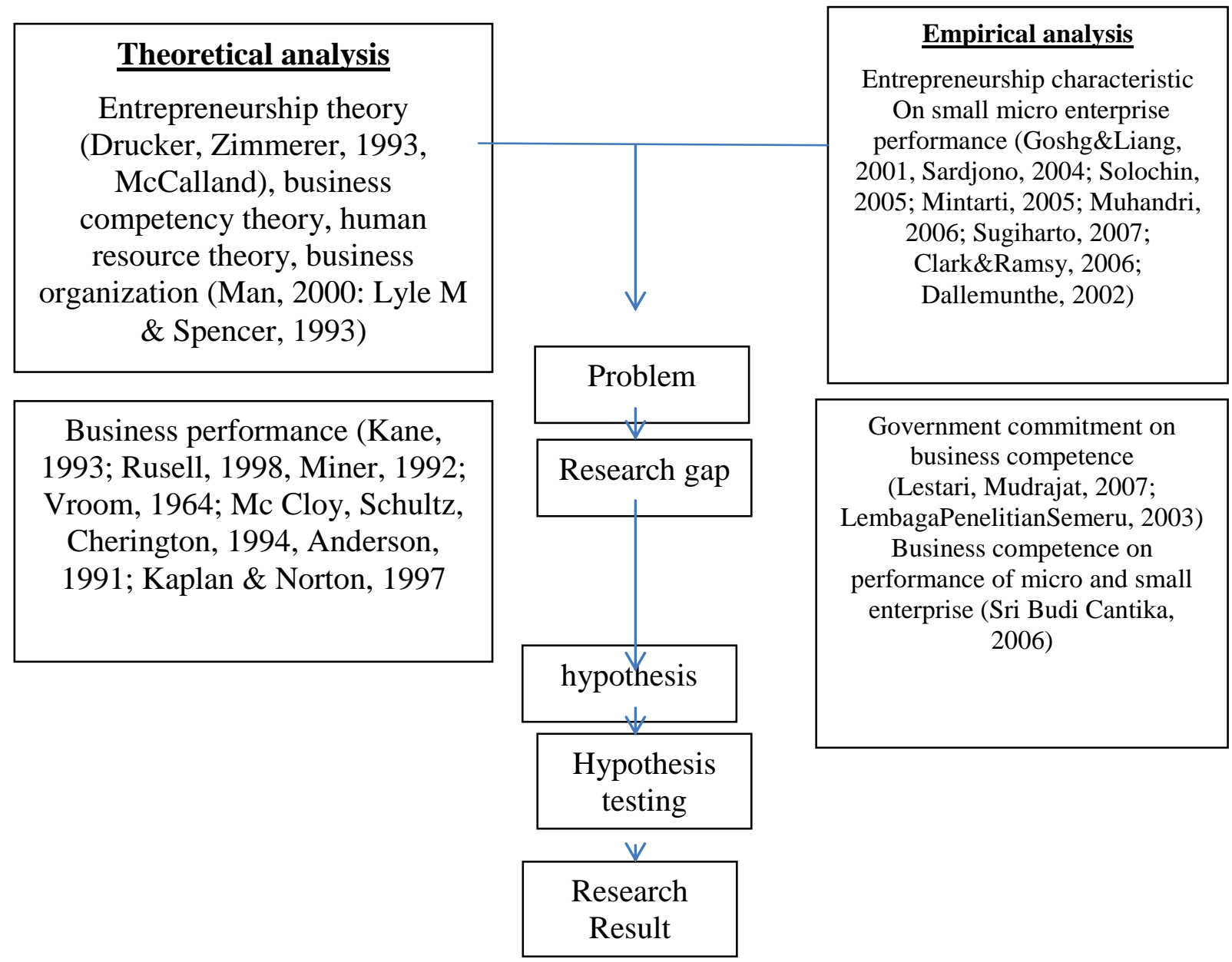

Figure: thinking process frame

\section{Research Hypothesis}

Based on theoretical analysis and empirical analysis, hypothesis is formulated as follow

H1: entrepreneurship characteristic effect significantly business competence

$\mathrm{H} 2$ : entrepreneurship characteristic effect significantly on small micro enterprise performance

H3: government commitment affect significantly on business competence

H4: government commitment affectsignificantly on small micro enterprise performance

H5: business competence affect significantly on small micro business performance 


\section{Research design}

The research is designed to answer formulated problem and objective that should be reached and to test hypothesis. Objective of the research was to obtain description on environment uncertainty, entrepreneurship characteristic, government commitment and business competence on micro and small business performance

\section{Research site}

This research was done on micro and small entrepreneur in East Kalimantan Province by taking location in Balikpapan. Population in this research is all micro and small entrepreneur in Balikpapan, East Kalimantan as following table.

Table 1: data of enterprise and business scale in Balikpapan

\begin{tabular}{|c|c|r|r|r|}
\hline No. & Business Scale & Fix Palace & Moving Palace & Total \\
\hline 1 & Small Enterprise & 9.059 & 3.803 & 12.862 \\
\hline 2 & Micro Enterprise & 21.431 & 14.423 & \\
\hline & Total & $\mathbf{3 0 . 4 9 0}$ & $\mathbf{1 8 . 2 2 6}$ & \\
\hline
\end{tabular}

Source: Deprindakop of Balikpapan

\section{Sample}

In order to make representative sample, in this research is determine sample is calculated using Slovin equation in Umar $(2004,108)$ that is

where

\begin{tabular}{r|}
\hline $\mathbf{n}=$ \\
$\mathbf{1}+\mathbf{N ~ e}^{2}$ \\
\hline
\end{tabular}

$\mathrm{n}=$ amount of sample

$\mathrm{N}=$ amount of population

$\mathrm{e}=$ percentage of tolerable inaccuracy slack due to sampling

using $5 \%$ in accuracy and population of 48,716 entrepreneur, sample in this research is

$$
\begin{array}{ccc}
\mathrm{n} & = & \begin{array}{c}
48.716 \\
\mathrm{n}
\end{array} \\
\mathrm{n}=396,75= & \frac{48.716}{1+(48.761)(0,05)^{2}} \\
= & \underline{\mathbf{3 9 7} \text { entrepreneurs. }}
\end{array}
$$

It is rounded into 400 entrepreneurs as respondents

6. Concept definition

1. Entrepreneurship characteristic refer to five factors of adapted to change, ability to risk failure, desire of growth, take advantage of the opportunity, and ability to search and having knowledge

2. Government commitment refers to government policy on small micro enterprise development including capital access improvement, entrepreneurship development and human resource, increase in product market opportunity and reform and regulation

3. Business competence refers to knowledge, skill and ability. Baum et al (2002) compose some variables explaining business competence: knowledge, cognitive ability, self management, administration, human resources, decisions skill, leadership, opportunity recognition, and opportunity development.

4. Performance of small micro enterprise is result achieved by small entrepreneur from running their business measured in financial aspect, customer, internal efforts and learning and growth.

\section{Operational definition}

1. First variable (X1) entrepreneurship characteristic consist of adapted to change (X11), ability to risk failure (X12), desire of growth (X13), take advantage of the opportunity (X14), ability to search and having knowledge (X15)

2. Third variable (X2), government commitment refer to development of small micro enterprise include: capital access improvement (X21), entrepreneurship and human resources development (X22), product market opportunity improvement (X23) and reform and regulation (X24) 
3. Fourth variable (Y1), business competence, refers to knowledge (Y11), skill (Y12), and ability (Y13

4. Fourth variable (Y2) business competence refer to knowledge (Y21, skill (Y22) and ability (Y23)

\section{Field study}

\section{Data Source And Data Collection Instrument}

Primary data was obtained from interview and questionnaire filling related to variables of environmental uncertainty, government commitment, entrepreneurship characteristic, business competence and businessperformancemeasured with balance scorecard. To obtain primary data, field research was done using questionnaire, observation and interview.

\section{Library research}

Library research was required to collect secondary data and to support, complete and improve primary data. Secondary data was collected by reviewing previous researches, reports from related institution and data on small micro enterprise development in research site.

\section{Research procedure}

a. Test of validity

Technique used is item analyses (Sugiyono, 1999), in which each sore on each question is correlated with total score of all questions to the variable using product moment correlation. Minimal condition for validity is $r>0.30$

b. Test of reliability

Test of reliability is an index indicating the extent which the instrument is reliable. The rest of reliability used Alpha Cronbach, where instrument can be said reliable when it has alpha >0.05 (Arikunto, 1992).

\section{Analytical method}

\section{Data Analysis Method And Hypothesis Testing}

Path analysis is done to make estimation of causal association among variables. Data processing and analysis was done using Structural Equation Modeling (SEM) with software AMOS 6.0 to test effect of environmental uncertainty and managerial characteristic of small micro enterprise on household welfare in Balikpapan municipality in East Kalimantan province. Steps in Structural EquationModeling is to build model based on theory (substance) consisting of (a) build association between variable and construct, (b) change association of variable and construct to SEM, (c) select matrix input and estimating model, (d) do assessment on model made, (e) evaluation of accepting criteria of a model.

Table 2. Entrepreneurship characteristic, Regression weight (factor loading)

\begin{tabular}{|c|c|c|c|c|}
\hline \multirow{2}{*}{ Variabel laten } & $\begin{array}{c}\text { Variabel } \\
\text { Indikator }\end{array}$ & $\begin{array}{c}\text { Regression Weight } \\
\text { (Factor Loading) }\end{array}$ & $\begin{array}{c}\text { Critical.Ratio. } \\
\text { (CR } \geq 2.58)\end{array}$ & Ref. \\
\hline \multirow{4}{*}{$\begin{array}{c}\text { Entrepreneurship } \\
\text { Characteristic } \\
\text { (X2) }\end{array}$} & $\mathrm{X} 1.1$ & 0,341 & 6,294 & Significant \\
\cline { 2 - 5 } & $\mathrm{X} 1.2$ & 0,560 & 10,847 & Significant \\
\cline { 2 - 5 } & $\mathrm{X} 1.3$ & 0,618 & 11,733 & Significant \\
\cline { 2 - 5 } & $\mathrm{X} 1.4$ & 0,627 & 12,271 & Significant \\
\hline
\end{tabular}

Source: result of data processing with SEM

Table 3.government commitment, Regression weight (factor loading)

\begin{tabular}{|c|c|c|c|c|}
\hline \multirow{2}{*}{ Variabel laten } & $\begin{array}{c}\text { Variabel } \\
\text { Indikator }\end{array}$ & $\begin{array}{c}\text { Regression Weight } \\
\text { (Factor Loading) }\end{array}$ & $\begin{array}{c}\text { Critical.Ratio. } \\
\text { (CR } \geq 2.58)\end{array}$ & Ref. \\
\hline \multirow{3}{*}{$\begin{array}{c}\text { Government Commitment } \\
\text { (X3) }\end{array}$} & $\mathrm{X} 2.1$ & 0,689 & 14,762 & Significant \\
\cline { 2 - 5 } & $\mathrm{X} 2.2$ & 0,752 & 16,391 & Significant \\
\cline { 2 - 5 } & $\mathrm{X} 2.3$ & 0,868 & 19,775 & Significant \\
\cline { 2 - 5 } & $\mathrm{X} 2.4$ & 0,678 & 14,398 & Significant \\
\hline
\end{tabular}

Source: result of data processing with SEM

Table 4. Business competence, Regression weight (factor loading)

\begin{tabular}{|c|c|c|c|c|}
\hline \multirow{2}{*}{ Variabel laten } & $\begin{array}{c}\text { Variabel } \\
\text { Indikator }\end{array}$ & $\begin{array}{c}\text { Regression Weight } \\
\text { (Factor Loading) }\end{array}$ & $\begin{array}{c}\text { Critical.Ratio. } \\
\text { (CR } \geq 2.58)\end{array}$ & Ref. \\
\hline \multirow{2}{*}{$\begin{array}{c}\text { Business competence } \\
\text { (Y1) }\end{array}$} & Y1.1 & 0,525 & 4,699 & Significant \\
\cline { 2 - 5 } & Y1.2 & 0,728 & 6,544 & Significant \\
\cline { 2 - 5 } & Y1.3 & 0,684 & 6,735 & Significant \\
\hline
\end{tabular}


Source: result of data processing with SEM

Table 5. Performance of small micro enterprise, Regression weight (factor loading)

\begin{tabular}{|c|c|c|c|c|}
\hline Variabel laten & $\begin{array}{c}\text { Variabel } \\
\text { Indikator }\end{array}$ & $\begin{array}{c}\text { Regression Weight } \\
\text { (Factor Loading) }\end{array}$ & $\begin{array}{c}\text { Critical.Ratio. } \\
\text { (CR } \geq 2.58)\end{array}$ & Ref. \\
\hline \multirow{3}{*}{$\begin{array}{c}\text { Performance Of Small } \\
\text { Micro Enterprise } \\
\text { (Y2) }\end{array}$} & Y2.1 & 0,547 & 6,736 & Significant \\
\cline { 2 - 5 } & $\mathrm{Y} 2.2$ & 0,715 & 6,544 & Significant \\
\cline { 2 - 5 } & $\mathrm{Y} 2.3$ & 0,502 & 6,735 & Significant \\
\cline { 2 - 5 } & $\mathrm{Y} 2.4$ & 0,547 & 7,366 & Significant \\
\hline
\end{tabular}

Source: result of data processing with SEM

The model is tested with goodness of fit index, as presented in below table

Table 6.evaluation model fit criteria (Goodness of Fit Index) for modification model

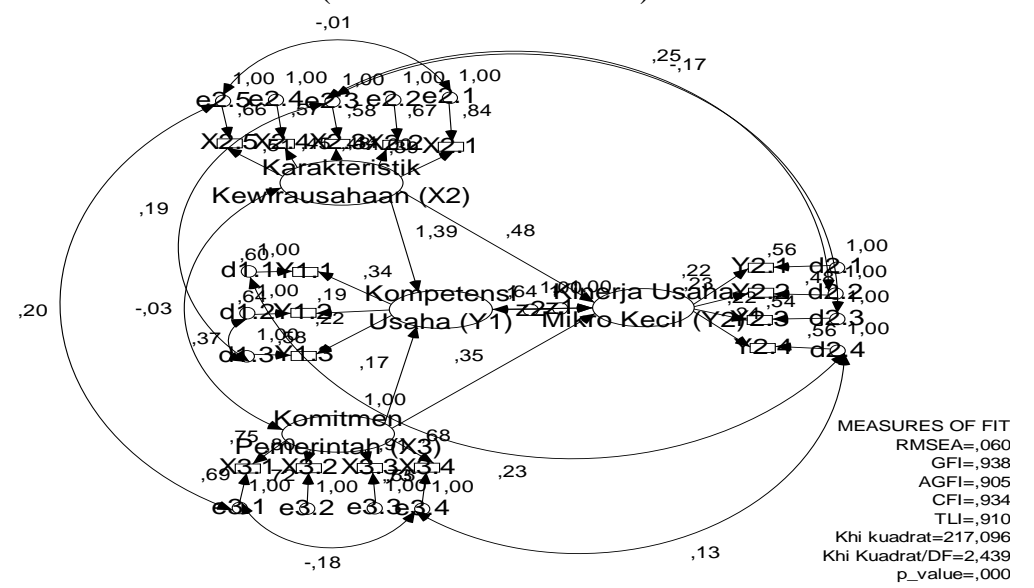

\begin{tabular}{|c|l|c|c|c|}
\hline No. & \multicolumn{1}{|c|}{ Goodness of Fit Index } & $\begin{array}{c}\text { Cut of Value /Nilai } \\
\text { Kritis }\end{array}$ & $\begin{array}{c}\text { Nilai Hasil } \\
\text { Pengujian }\end{array}$ & $\begin{array}{c}\text { Kreteria } \\
\text { Penerimaan }\end{array}$ \\
\hline 1 & Che-square $\left(\chi^{2}\right)$ & Sekecil mungkin & 217,096 & Not Significant \\
\hline 2 & CMIND/DF & $1.0-2.0$ & 2,439 & Good ( fit ) \\
\hline 3 & Goodness of Fit Index (GFI) & $\geq 0,90$ & 0,938 & Good ( fit ) \\
\hline 4 & $\begin{array}{l}\text { Adjustid Goodness of Fit Index } \\
\text { AGFI) }\end{array}$ & $\geq 0,90$ & 0,905 & Good ( fit ) \\
\hline 5 & Tucker Lewis Index (TLI) & $\geq 0,90$ & 0,910 & Good ( fit ) \\
\hline 6 & $\begin{array}{l}\text { Comparative Fit Index (CFI) } \\
\text { Root Mean Square Error } \\
\text { approximatin } \\
\text { RMSEA) }\end{array}$ & $\leq 0,0,90$ & 0.934 & Good ( fit ) \\
\hline
\end{tabular}

Source: processed from model testing with SEM

*: chi Square $\left(\chi^{2}\right)$ of 278.570 means there is great difference, which means insignificant.

**: probability $(\mathrm{p})=0.000$, les then cut of value 0.05 may be considered marginal. Term marginal is used by Hair et al (1998)Source: processed from Goodness of Fit test

\section{Multivariate outlier}

Base for calculatingmahalanolis distance, is on chi square freedom level 3 in probability 0.001 is $(3 ; 0.001)=286,680$. So exceedingdata is multivariate outlier. Based on AMOS program, case or following respondent reflect multivariate outlier (Ferdinand, 2006, p.354)

Table 7. Regression Weight

\begin{tabular}{|c|l|c|r|r|r|r|r|}
\hline & & & Estimate & S.E. & C.R. & P & Label \\
\hline $\begin{array}{c}\text { Business } \\
\text { Competence } \\
\text { (Y1) }\end{array}$ & $<---$ & $\begin{array}{c}\text { Entrepreneurship Characteristic } \\
\text { (X2) }\end{array}$ & 1,482 &, 311 & 4,770 & $* * *$ & Significant \\
\hline $\begin{array}{c}\text { Business } \\
\text { Competence }\end{array}$ & $<---$ & $\begin{array}{c}\text { Government Commitment } \\
\text { (X3) }\end{array}$ &, 185 &, 105 & 1,769 &, 077 & Not Significant \\
\hline
\end{tabular}


Effect Of Entrepreneurship Characteristic, Government Commitment And Business Competence...

\begin{tabular}{|c|r|r|r|r|r|r|l|}
\hline & & Estimate & \multicolumn{1}{|c|}{ S.E. } & C.R. & \multicolumn{1}{c|}{ P } & Label \\
\hline (Y1) & & & & & & \\
\hline $\begin{array}{c}\text { Performance Of Small } \\
\text { Micro Enterprise } \\
\text { (Y2) }\end{array}$ & $<---$ & $\begin{array}{c}\text { Business } \\
\text { Competence } \\
\text { (Y1) }\end{array}$ &, 154 &, 187 &, 823 &, 411 & Not Significant \\
\hline $\begin{array}{c}\text { Performance Of Small } \\
\text { Micro Enterprise } \\
\text { (Y2) }\end{array}$ & $<--$ & $\begin{array}{c}\text { Entrepreneurship Characteristic } \\
\text { (X2) }\end{array}$ & 1,305 &, 410 & 3,185 &, 001 & Significant \\
\hline $\begin{array}{c}\text { Performance Of Small } \\
\text { Micro Enterprise } \\
\text { (Y2) }\end{array}$ & $<--$ & $(\mathrm{X} 2)$ &, 416 &, 122 & 3,395 & $* * *$ & Significant \\
\hline
\end{tabular}

Source: data processing with SEM

Based on theory review and previous research result, hypothesis is built and tested with structural equation modeling (SEM) with software AMOS (Analysis of Moment Structure), indicating following results:

(1) Entrepreneurship characteristic affect positively and significantly on business competence of small micro enterprise with path coefficient 1.482

(2) Entrepreneurship characteristic effect positively and significantly on performance of small micro enterprise with path coefficient 1.305

(3) Government commitment influence positively and not significant on business competence on small micro enterprise with path coefficient 0.185

(4) Government commitment influence positively and significantly on performance of small micro enterprise with path coefficient 0.416

(5) Business competence influence positive and significantly on performance of small micro enterprise performance with path coefficient 0.789

\section{Result Of Hypothesis Test}

Result of calculation on goodness of fit in Amos 6.00 program indicate that confirmatory analysis and Structural Equation Modeling (SEM) in this research can be accepted according to model fit with Chisquare $=278.570$, with probability=0.000, CMIND/DF=2.110, Goodness of Fit Index $(\mathrm{GFI})=0.932$, $\mathrm{m}$ Adjusted Goodness of Fit Index (AGFI)=0.903, Tucker Lewis Index (TLI) 0.903, Comparative Fit Index $(\mathrm{CFI})=0.925$, Root Mean Square Error Approximation (RMSEA)=0.052. According to table 5.21, based on the fit model, test of seven hypotheses may be done.

1. Entrepreneurship characteristic influence business competence

Based on structural model analysis in SEM, entrepreneurship characteristic is proved influencing business competence. It is indicated with table 5.20 explaining coefficient regression route of entrepreneurship characteristic on business competence is 0.830 with $\mathrm{CR}=4.678$ and $\mathrm{PV}=0.000$. Because $\mathrm{CR}>1.96$ and $\mathrm{P}<0.05$, hypothesis 3 is accepted.

2. Entrepreneurship characteristic influence small micro enterprise performance

Result of structural analysis with SEM model on direct effect indicated entrepreneurship characteristic influence positive significantly on small micro enterprise performance. It is indicated with table 5.20 explaining regression coefficient of entrepreneurship characteristic on business performance is 0.763 with $\mathrm{CR}=2.986$ and $\mathrm{PV}=0.003$ ). Because $\mathrm{CR}>1.96$ and $\mathrm{P}<0.05$, hypothesis 4 is accepted

3. Government commitment influence business competence

Result of SEM structural analysis on direct influence indicated that government commitment (X2) has positive and not significant effect on business competence (Y1) of small micro enterprise entrepreneur in Balikpapan. It is revealed in table 5.20, explaining regression coefficient of government commitment (X3) on business competence (Y1) of 0.103 with $\mathrm{CR}=1.758$ and $\mathrm{PV} 0.079$. Because $\mathrm{CR}<1.96$ and $\mathrm{P}>0.05$, hypothesis 5 is denied

4. Government commitment influence small micro enterprise performance

Result of SEM structural analysis on direct influence indicated that government commitment (X2) has positive and not significant effect on small micro enterprise performance (Y2) in Balikpapan. It is revealed in table 5.20, explaining regression coefficient of government commitment (X3) on small micro enterprise performance (Y2) of 0.227 with $\mathrm{CR}=0.316$ and $\mathrm{PV} 0.752$. Because $\mathrm{CR}<1.96$ and $\mathrm{P}>0.05$, hypothesis 6 is denied.

5. Business competence influence small micro enterprise performance

Result of SEM structural analysis on direct influence indicated that business competence (Y1) affect positively and significantly on small micro enterprise performance (Y2) in Balikpapan. It is revealed in table 5.20, explaining regression coefficient of business competence (Y1) on small micro 
enterpriseperformance (Y2) of 0.060 with $\mathrm{CR}=6.163$ and $\mathrm{PV} 0.000$. Because $\mathrm{CR}<1.96$ and $\mathrm{P}>0.05$, hypothesis 7 is accepted

6. Variable of entrepreneurship characteristic

Result of the research indicated that entrepreneurship characteristic that is measured with desire adapt to change $(C R=6.294>2.00)$, ability to risk failure $(C R 10.847>2.00)$, ability to search $(\mathrm{CR} 11.733>2.00)$, desire of growth $(\mathrm{CR} 12.271>2.00)$ and take advantage of opportunity $(\mathrm{CR}=11.807>2.00)$, indicated with critical ratio of echdimension with less probability than $0.05(\mathrm{PV}<0.05)$.

7. Variable of government commitment

The research indicated that government commitment variable measured with access to obtain capital (CR of 14.762>2.00), entrepreneurship development ( $\mathrm{CR}=16.391>2.00$ ), market opportunity development (CR of $19.755>2.00)$ and reform and regulation (CR of $14.398>2.00)$ of each dimension with less probability than $0.05(\mathrm{PV}<0.05)$.

8. Business competence variable

The result indicated that business competence measured with knowledge (CR $4.699>2.00$, skill (CR, 6.544 $>2.00)$ and ability (CR, $6.735>2.00)$ reveal probability less than $0.05(\mathrm{PV}<0.05)$.

9. Small micro enterprise performance variable

The result indicate that variable of small micro businessperformance with indicators of financial perspective (CR $6.736>2.00)$, customer perspective (CR $6.544>2.00)$, internal business process $(\mathrm{CR} 6.735>2.00)$ and growth and learning perspective $(\mathrm{CR} 7.366>2.00)$ with probability of each factor is less than $0.05(\mathrm{PV} 0.05)$

\section{Conclusion}

\section{Closing}

This research proved that entrepreneurship characteristic influence positively and significantly on business competence and influence positively and not significantly on performance. Government commitment influence positively and not significantly on business competence and influence positively and significantly on business performance.

Conclusion based on the research problem is that all variables studied have positive effect on dependent variable. Entrepreneurship characteristic affects positively on business competence and small micro enterprise performance and government commitment influencepositively business competence and small micro enterprise performance and business competence influence positively on micro business performance. Of seven variables studied, three variables has significant: entrepreneurship characteristic on business competence, government commitment on business performance, while three other variable has insignificant effect; environment uncertainty on business competence and business performance, entrepreneurship characteristic and government commitment on small micro enterprise performance. To it may be concluded that further research should be done to get result supporting or denying previous theories.

\section{Recommendation}

After learning all research process related to effect of variable, then for operational and for further research,development of small micro enterprise performance should be done by considering environment complexity, environmental change and environmental support with following. Some recommendations are proposed as follows.

1. Development of business competence should consider entrepreneurship characteristic done by

a) Competence of small micro enterprise should increase capability to adapt change with new technique and proactive approach

b) Competence of small micro enterprise should increase capability to develop business and win competition

c) Competence of small micro enterprise should improve capability to search new knowledge

2. In addition, development of business competition should also consider entrepreneurship characteristic by following measures

a) Government, BUMN, bank should improve knowledge, skill and business capability of small micro enterprise actor in Balikpapan by assistance through partnership in capital, marketing accounting, manufacture technique and distribution

b) Middle and big enterprise may also give assistance in marketing, accounting, manufacturing technique and distribution training

3. To improve performance of small micro enterprise

a) Government should keep conducivesituation so small micro enterprise actors can run business well by providing broader opportunity to small micro enterprise actor or by limiting new shopping mall

b) Government should regulate and protect small micro enterprise actor to be able to run business well with easiness in permit, access to capital and tax matter 
4. Improving performance of small micro enterprise in Balikpapan should consider business competence by

a) increasing business knowledge, skill and business capability

b) Knowledge, skill and capability should be increased to increase profit by increasing manufacture technique.

\section{References}

[1]. Bank Indonesia, (2005), Hasil Penelitian Profil Usaha Mikro, Kecil dan Menengah (UMKM) di Indonesia. Biro Kredit Bank Indonesia

[2]. Cahyono, Bambang Tri, (1999), Riset Pemasaran dan Kumpulan Tulisan Ilmiah, Penerbit IPWI Jakarta.

[3]. Faisal, Tri Jatmiko wahyu Prabowo, (2008), Pengaruh Intensitas Persaingan Pasar, Strategi Dan Ketidakpastian Lingkungan, Yang Dirasakan Terhadap Penggunaan informasi Sistem Akuntansi Manajemen Dan Kinerja Unit Bisnis. FakultasEkonomiUniversitasDiponegoro, E-Mail: Fe Faisal@Yahoo.Co.IdJaai Volume 10 No. 1, Juni 2006: 45 - 63

[4]. Kodrat, David Sukardi,(2009) Manajemen Strategis Membangun Keunggulan Bersaing Era Global di Indonesia Berbasis Kewirausahaan, Edisi Pertama, Penerbit Graha Ilmu, Yogyakarta

[5]. Krupp, Alexander Ebner (2006) Jurnal Ekonomi \& Perilaku OrganisasiVol. 59 497-515Lembaga, kewirausahaan, dan dasar pemikiran tentang pemerintah: Garis besar Schumpeter, teori Negara , Fakultas Ekonomi, Hukum dan Ilmu Sosial,Universitas Erfurt, Nordhauserstrasse 63, 99089 Erfurt, Jerman.

[6]. Littunen, Hannu, University of Jyvaskyla (2000), School of Bussines and Economic Centres for Economic Research, Jyvaskyla Finland, International Journal of Entrepreneurial Bihaviour \& Research Vol 6 No 6

[7]. Man, Thomas WY, Lau Theresa, Ed Snape (2008), Kompetensi kewirausahaan dan kinerja usaha kecil dan menengah: suatu penyelidikan melalui kerangka daya saing Jurnal Usaha Kecil dan Kewirausahaan, Summer.

[8]. Muryati (2004), Disertasi ,Muryati (2004), Itensitas strategi bersaing dan kinerja ekspor pada industri kecil produk kerajinan kayu di Propinsi Jawa Timur. Di 9 kabupaten dan 6 kota daerah daerah sentra industri yang mempunyai banyak banyak perusahaan.

[9]. Priyanto, Sony Heru (2004), Disertasi Pascasarjana Universitas Brawijaya Malang. Pengaruh Lingkungan Eksternal, Kewirausahaan dan Kapasitas manajemen terhadap kinerja usahatani

[10]. Rahayu, Minarti (2005), Disertasi Pascasarjana Universitas Brawijaya Malang.Hubungan antara lingkungan, Kewirausahaan, Organisasi dan Kinerja berdasarkan model Pembelajaran Organisasi (Studi pada Usaha Kecil Etnis Tionghwa dalam Industri Roti/Kue di Kota Malang.

[11]. Rakib, Muhammad, (2007), Pengaruh Komunikasi antar Pengusaha, pelanggan, pembelajaran Wirausaha dan sikap Kewirausahaan terhadap kinerja usaha kecil ( studi pada usaha kecil mebel kayu di kota Parepare).

[12]. Solichin, Endang, (2005). Kajian Karakteristik Entrepreneurship dan iklim usaha serta kontribusi terhadap kemajuan usaha (studi pada agroindustri pangan pada skala usaha kecil di Kediri.

[13]. Suryana (2004), Memahami Karakteristik Kewirausahaan, Direktorat Pendidikan Menengah Kejuruan Direktorat Jenderal Pendidikan Dasar Dan Menengah Departemen Pendidikan Nasional

[14]. Sutarno, Widayanto \& Andi Wijayanto, (2005), Pengaruh karakteristik Wirausahaan terhadap tingkat keberhasilan usaha (studi kasus pada sentra usaha kecil pengasapan ikan di Krobokan Semarang.

[15]. Syafruddin, Muchammad ,Pengaruh Struktur Kepemilikan Perusahaan Pada Kinerja: Faktor Ketidakpastian Lingkungan Sebagai Pemoderasi Fakultas Ekonomi Universitas Diponegoro, Jaai Volume 10 No. 1, Juni 2006: 85 - 99

[16]. Widoatmodjo, Sawidji.(2005) New Business Model, Strategi Ampuh Memenangi Bisnis di

[17]. Abad ke 21, Penerbit PT Alex Media Komputindo Kelompok Gramedia 